practices by observing that, "I cannot accept that the patient must understand the precise physiological process involved before he can be said to be capable of understanding the nature and likely effects of the treatment and can consent to it".

The decision as to whether any surgery, including psychosurgery, is appropriate for a patient or not is entirely and exclusively a medical one and it can only properly be made by clinicians personally responsible for the continuing care of the patient. The "goserelin" judgment included an elegant observation in this context: "It is not entirely clear why it is appropriate for non-medically qualified people to be consulted on the desirability of medical treatment, having regard to the likelihood of it alleviating the patient's condition or preventing its deterioration". And that is really all that we need to be concerned about. Would the Commission please acknowledge this?

The Geoffrey Knight Unit for Affective Disorders Brook General Hospital

London SE18

Editorial note: see Mental Health Act Commission. (Louis Blom-Cooper), Psychiatric Bulletin, June 1989, 13, 309 310).

\section{Consent to ECT}

\section{DeAr SiRs}

I read with interest 'Patients' perceptions and knowledge of electro-convulsive therapy' (Psychiatric Bulletin, April 1989, 13, 161-165). In a study of patients' views on ECT following a course of treatment (Benbow, 1988) only six $(12 \%)$ of 54 patients had a full understanding of the procedures involved in ECT. Another $13(25 \%)$ had some partial knowledge, and $33(64 \%)$ had no idea or only knew about the general anaesthetic. These figures are similar to those reported by Malcolm, and must be a cause for concern among those psychiatrists who prescribe ECT.

Despite our procedures for informed consent, it appears that patients have little understanding of what ECT involves. Although one may feel intuitively that a fuller understanding of ECT should assist in alleviating patient anxiety this has not been demonstrated, nor has the optimum method of seeking consent. Patients who were shown a videotape to inform them about ECT during the process of seeking consent were less sure that they had sufficient information on which to decide whether to accept treatment than those who were not shown it (Baxter et al, 1986). A number of questions arise from these observations: what do our patients want to know about the treatment? Are psychiatrists justified in forcing knowledge on patients who may not want it? Does a greater understanding of ECT increase or decrease the likelihood of a patient consenting to receive treatment?

These are important issues, but difficult to confront. At present we operate using various individual practices. Although consent is a contentious issue, it cannot be avoided and those psychiatrists who prescribe ECT might be advised to review their consent procedure and the way in which patients and their relatives are informed about the treatment.

Department of Psychiatry for the Elderly

Central Manchester Health Authority

\section{References}

BAXTER, L. R., Roy-BYrne, P., LISTON, E. H. \& FaIRbanks, L. (1986) Informing patients about electroconvulsive therapy: effects of a videotape presentation. Convulsive Therapy, 2, 25-29.

BENBOW, S. M. (1988) Patients views on electroconvulsive therapy on completion of a course of treatment. Convulsive Therapy, 4, 146-152.

\section{How much protection is provided to medical practitioners by the Mental Health Act 1983?}

\section{DeAR Sirs}

Section 139 of the Mental Health Act 1983 can give a limited immunity from prosecution in both civil and criminal proceedings for actions purporting to be done in the pursuance of the Act by requiring leave before commencing actions. There are exceptions to this protection for actions which have been performed in bad faith or without reasonable care. Under Section 139 it is necessary for a patient to seek leave of the High Court before civil proceedings can commence. Criminal proceedings can only be brought by the Director of Public Prosecutions or with his consent. Proceedings for offences under the Mental Health Act 1983, i.e. forgery, false statements (Section 126), ill treatment of patients (Section 127), assisting patients to absent themselves without cause (Section 128), or obstruction (Section 129) are solely initiated by the Director of Public Prosecutions.

Although Section 139 gives protection to individuals in this way it does not give any protection either to the Secretary of State or to a health authority. A patient does not require leave from the High Court or the consent of the Director of Public Prosecutions if he wishes to sue these bodies. How much protection 
does Section 139 give to psychiatrists, as individuals, in everyday practice?

In a recent judgment by Judge Henry in the case of Furber $v$. Kratter the protection from litigation for those implementing the Act may be less than first appears. Furber was an in-patient in Moss Side Special Hospital when she attacked a nurse in a vicious and unprovoked manner. The event was witnessed by Dr Kratter. Furber was placed in a seclusion room for 16 days as a result of her disturbed behaviour. She asked the High Court for leave to commence proceedings for negligence; which in law she would be required to prove that the event had caused temporary or permanent physical or mental injury. She also asked leave to commence proceedings for false imprisonment; which would require, in the setting of a detained patient in a Special Hospital, to show that she was held in unacceptable conditions of detention.

In his judgment Judge Henry referred to Winch $v$. Jones (1986) which looked at the purpose of Section 139 and the reasons why a statement of claim by a patient should be struck out. He decided that a patient who was asking leave under this Section does not need a stronger claim than would be ordinarily required. The Section was to protect against the possibility of a mental patient making wild or exaggerated allegations which are eventually found to be baseless. However, on the other side of the coin, it was appreciated that mental patients are more vulnerable than the general population to exploitation or abuse. Lord Justice Parker stated that the purpose of Section 139 was to prevent persons being exposed to or harassed by clearly hopeless actions. The test to apply for leave of the High Court "is not a trial of the documents and nor is it in any way a dress rehearsal of the strengths and weakness of the action. It is instead a relatively wide meshed sieve through which claims are processed, and many claims may properly get through it even though the judge granting leave may think that the claim at the end of the day may fail". He should only refuse leave of the action if it is unfair to the defendants. Section 139 refers to proceedings rather than the individual causes of action which in the case of Furber $v$. Kratter were overlapping. There may be occasions when leave is granted for one proceeding but not another.

The result of this judgment shows that the Section 139 gives very little immunity from prosecution even if the actions were performed in apparent good faith and with apparent reasonable care. The section appears to protect doctors only from wilful or exaggerated claims by detained patients but it does not provide any greater degree of protection.

M. W. D. Rowlands

Hackney Hospital

London E9

\section{References}

Furber v. Kratter (1988) QB CO559.

Winch v. Jones (1986) 1 QB 296.

\section{Section 136 of the Mental Health Act}

\section{DeAR Sirs}

I read with interest Dr Wallis's account on the Royal Society of Health dealing with Section 136 of the Mental Health Act (Psychiatric Bulletin, March $1989,13,144-147)$. I would like to concur with Professor Bluglass's reported statement that Section 136 is used outside London and, indeed, its high rate of usage in a rural area has been documented (Fahy et al, 1987).

A colleague and I are currently looking at the converse of this situation, i.e. how an area with a below average usage of Section 136 deals with community psychiatric emergencies.

Hinchingbrooke Hospital, Huntingdon and Fulbourn Hospital, Cambridge

\section{Reference}

Fahy, T. A., Bermingham, D. \& Dunn, J. (1987) Police admissions to psychiatric hospitals, a challenge to community psychiatry? Medicine, Science and the Law, 27 October (4N), 263-268.

\section{Training in community psychiatry*}

\section{Dear Sirs}

The move to community based care has been widespread, and is not likely to reverse. It exposes psychiatrists to an experience often very different from that gained in a traditional mental hospital training. Established psychiatrists have adapted their practice to encompass current ideas, but training has been slower to adapt to the changing educational requirements of juniors, who will spend much of their working lives in such a system. Connolly \& Marks (1989) have begun the debate on types of training for community care, and have produced a long list of areas in which they believe knowledge to be required.

It is prudent to look at the experience of those for whom the practice of community-based psychiatry is long established. In the United States there are several training programmes in community work. One of the longest established, at the Johns Hopkins

*Based on a talk given at the Scottish Trainee's Day, Royal Edinburgh Hospital, March 1989. 